\title{
The Potency of Sea Fishery in West Sumatra
}

\author{
Melti Roza Adry ${ }^{1}$, Dewi Zaini Putri ${ }^{2}$, Novya Zulva Riani ${ }^{3}$, Joan Marta ${ }^{4}$ \\ ${ }^{1}$ Dept. of Economics, Faculty of Economics, Universitas Negeri Padang, Padang, Indonesia \\ $\triangle$ (e-mail) meltirozaadry@gmail.com \\ ${ }^{2}$ Dept. of Economics, Faculty of Economics, Universitas Negeri Padang, Padang, Indonesia \\ $\triangle$ (e-mail) putridewizaini@gmail.com \\ ${ }^{3}$ Dept. of Economics, Faculty of Economics, Universitas Negeri Padang, Padang, Indonesia \\ $\triangle$ (e-mail) novyazr@gmail.com \\ 4 Dept. of Economics, Faculty of Economics, Universitas Negeri Padang, Padang, Indonesia \\ $\square$ (e-mail) jomarta01@gmail.com
}

\begin{abstract}
West Sumatra is one of the Province in Indonesia that has potential of marine resources both public and marine waters. However, this potential has not been optimally managed so as not to contribute significantly to the welfare of the people and economic growth of West Sumatra Province. This analysis is aimed to produce a policy or strategy of marine fishery-based regional development in West Sumatra Province. The results of the study show that the leading commodities of marine fishery of West Sumatra Province were (1). species of small pelagic fish comprise of torpedo fish, talang-talang, bigeye, anchovy, greenstripe scad, yellowstripe scad and mackerel, (2). species of big pelagic fish comprise of selendang shark, frigate tuna, cowboy shark, indo-pacific king mackerel, bottle shark, black marlin, sail fish and mouse shark/monkey shark; (3). species of damersal fish comprose of senuk, peperek, large head hair tail, nomei/lomei fish, kapas-kapas, jenaha, gaji fish and giant trevally, and (4). species of coral fish are kerapu balong, kerapu Karang, yellow tail fish, and napoleon fish.
\end{abstract}

Keywords: marine fishery, commodity, regional development,

\section{Introduction}

West Sumatra is one of the provinces located on the west coast of Sumatra which has abundant marine and fisheries potential as one of the supporting sectors of economic growth in West Sumatra. Development of Marine and Fisheries sectors is an integral part of West Sumatra Regional Development, which is geographically very significant because that marine areas is part of exclusive economic zone (ZEE) around 51,060.23 $\mathrm{km}^{2}$ and public waters (four large lakes, rivers, ponds, and reservoirs) around $62,400 \mathrm{~km}^{2}$ exceeding the area from the mainland of West Sumatra Province. This fact and also the potential contained such as fish resources and environmental services (marine tourism, resorts, sports maritime and others), it is projected that marine and fisheries to be one of the main determinants factors of the economy of West Sumatra in the future.

Marine and Fishery Sector in West Sumatra economy has a big role for the economy such as the source of employment, the source of animal protein derived from fish, and the source of foreign exchange. It has 185 small islands with the length $375 \mathrm{~km}^{2}$ extending from Pasaman Barat to Pesisir Selatan, the length will be greater if it includes beaches in the Mentawai Islands so it has considerable potential for fisheries development.

This is supported by the production of marine fisheries that are only found in seven districts of the City that is located along the coast. The seven districts of the City are Mentawai Island District, Pesisir Selatan District, Padang Pariaman District, Agam District, Pasaman Barat District, Padang City and Pariaman City. Marine fisheries production in West Sumatra from 2011 to 2014 showed a positive trend but then declined in 2015. It decreased from 214,734 tons to 206,399 tons or decreased by 3.88 percents from the previous period. The decrease of production is due to the decrease of capture fishery production in Mentawai Island around 51.07 percent and in Padang Pariaman around 33.32 
percent in 2015. In addition, the decrease of marine fishery production is also highly determined by the means used by fishermen in the process of fishing. Central Bureau of Statistics records that the majority of fishermen in West Sumatra use boats with outboard motor as a means of fishing in the sea.

The decline in marine fisheries production leads to a lack of West Sumatra's ability to meet the high market demand for fresh marine fish. Increased demand for fresh and processed fish from neighboring provinces, sub-regional neighbors and other markets becomes a problem when quality qualifications and desired supply commitments cannot be fulfilled in West Sumatra. FAO data show that the need for fish consumption is increasing every year. The consumption of fish in the world per capita can reach $19.6 \mathrm{~kg}$ in 2021. Thus, means that coastal areas in West Sumatra have potential in the development of marine fishery commodities.

Another strategic issue of fisheries and marine is the high poverty rate of fishery communities in West Sumatra. This is evident from the high level of poverty in coastal areas. Mentawai Islands District is the coastal region with the highest poverty level compared to other regions in West Sumatra Province. Of the seven districts of the city located in the coastal areas, five of them have poverty levels above the average of West Sumatra Province. In addition, seen from the field of business, most of them work in agriculture sector including fishery sub-sector. Increasing the living standard of cultivators, fishermen and processors / marketing of fishery products conducted in an integrated and sustainable manner both at the provincial and municipal level as well as related institutions are expected to reduce poverty problems in the area.

Besides Capture Fisheries, West Sumatra also has potential for the development of Aquaculture Fisheries, freshwater, brackish and marine fisheries. This is supported by the existence of four lakes, ponds, reservoirs, and rivers. Besides, the potential of brackish and marine cultivation extends from Pasaman Barat to Pesisir Selatan Regency. The above potentials have not been utilized optimally so that there has not been a significant impact with the level of community welfare.

On the other hand, the economic growth shows a negative trend in the last four years but the growth rate of fishery sub-sector and percentage distribution of Fishery Sub-sector to total GDRP of West Sumatra shows positive trend, as shown in table 2. This indicates that fishery sub-sector has potential to be developed as one of the regional economic development strategies in West Sumatra and able to increase economic growth of West Sumatra. Although the distribution of the fishery subsector still contributes quite small but it can be developed as one of the determinant factors to decrease poverty in the coastal areas in West Sumatra.

Based on these previous conditions it is important to empower coastal communities in West Sumatra Province so as to reduce poverty and of course there is a need for a systematic and comprehensive program based on scientific studies in efforts to alleviate poverty and empower coastal communities. So that it will improve prosperity of society and economic growth of West Sumatra Province.

\section{Methods}

\section{Determination of Commodity - Leading Commodity Sub Sector of Sea Fishery}

Determining the leading commodities of sub sector of Sea Fishery of West Sumatra Province either from the type of species, productivity and selling value desired by the market. In addition, mapping of marine zones based on marine fisheries in West Sumatra Province is expected to be established by various local brands as leading products that have competitive and comparative advantages compared to other regions. For that purpose, an analysis using time series data is available at the Central Bureau of Statistics and Fisheries and Marine Service of West Sumatra Province. 
To determine commodities that have a comparative advantage is used Revealed Comparative Advantage (RCA) Analysis. RCA analysis is a quantitative analysis that compared the quantity of certain product in a region with other region using secondary data

$$
R C A=\frac{X_{i}^{A} / X^{A}}{X_{i}^{w} / X^{w}}
$$

where: $X_{i}^{A}$ is the value of commodity production i Province $\mathrm{A}$,

$$
\begin{aligned}
& X^{A} \text { is the total production value of all commodities } \mathrm{i} \text { in ProvinceA } \\
& X_{i}^{w} \text { is the value of commodity production } \mathrm{i} \text { in country } \mathrm{W} \\
& X^{w} \text { is the total production value of all commodities } \mathrm{i} \text { in country } \mathrm{W}
\end{aligned}
$$

a) If RCA $>1$ then the Province has a comparative advantage in producing I, higher than any other province in the country $\mathrm{W}$

b) If RCA $<1$ then the Province has no comparative advantage in producing I, higher than any other province in W Country

c) If $\mathrm{RCA}=1$ then the province has a comparative advantage in producing $\mathrm{i}$, the same as other provinces in $\mathrm{W}$ country

After obtaining the leading commodity in each region, then mapping is needed by using cluster analysis.

\section{Results and Discussion}

\section{Potential of West Sumatra Fishery}

West Sumatra Province is geographically located at $1^{\circ} \mathrm{LU}-3^{\circ} \mathrm{LS}$ and $98^{\circ} \mathrm{BT}-102^{\circ} \mathrm{BT}$. West Sumatra Province is bordered by North Sumatra Province in the north, Jambi and Bengkulu in the south, Indian Ocean in the east, and Riau Province in the west. Administratively, the province of West Sumatra consists of 19 districts / cities.

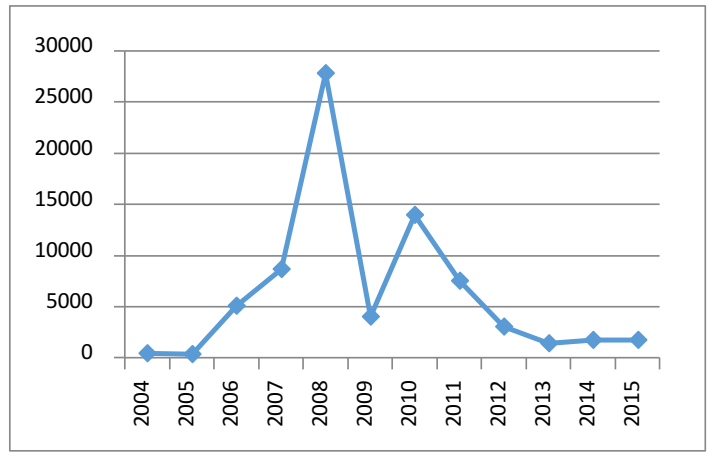

Figure 1 West Sumatra fishery production $2004-2015$

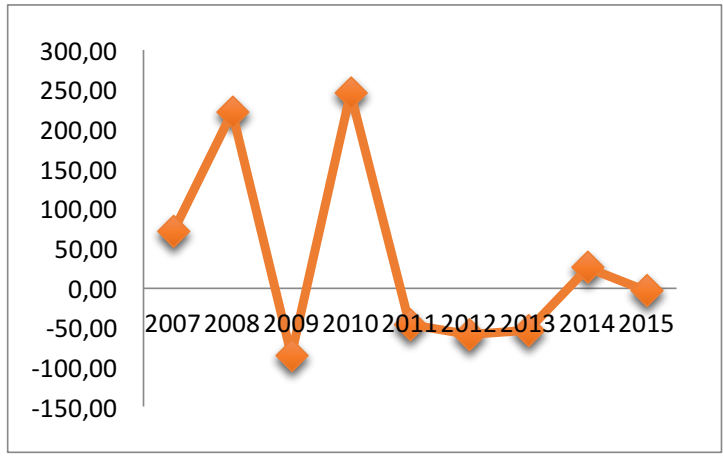

Figure 2 Sea fishery production in West Sumatra which is sold to TPI

West Sumatra Province has an area of $\pm 186,500 \mathrm{~km}^{2}$ of sea waters with long coastline 2,420,357 km and has 375 large and small islands. In 2016, the production of capture fisheries in West Sumatra Province reaches 303,105 tons or equivalent to IDR3,519,767,197,000. The largest contribution was obtained from Pasaman Barat regency which reached 102,441 tons, Pesisir selatan regency reach around 34,570 tons, Padang Pariaman regency whose production reached 26,677 tons. While in other districts, the production amount is still below 21.000 ton / year.

Meanwhile, in 2015 seen from the contribution of fisheries, Pasaman Barat regency is the region with the highest fishery production in West Sumatra with a contribution of 52 percent, followed by Pesisir Selatan regency of 18.89 percent and the lowest is Mentawai Islands District of 1.12 percent. 


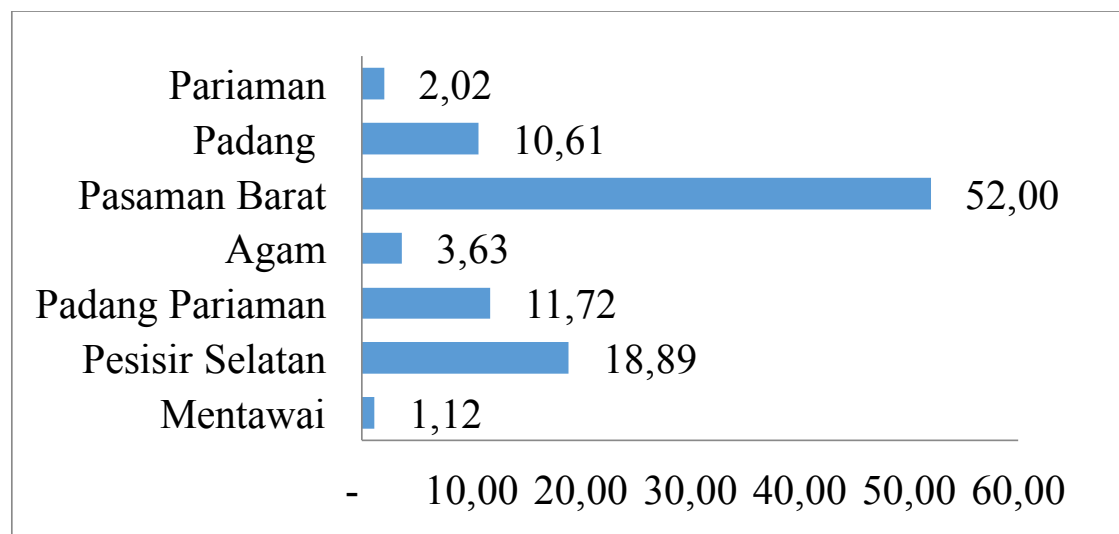

Figure 3 Contribution of cities/regencies to West Sumatra fishery production 2015

Capture fisheries production from marine waters landed in West Sumatra Province largely consists of groups of pelagic fish, group of Damersal fish, and non-fish groups (Crustacea and mollusca). Fish production is economically important in the pelagic fish group dominated by 5 species of fish, namely: cobs of cassava, skipjack, albakora, madidihang and Large eye tuna. As for the Damersal fish group, fish production that is economically valuable, important is dominated by fish species: lencam, red snapper, coral grouper, grouper balong and cucut. For the production of non-fish groups with significant economic value, they are dominated by: shrimp, white shrimps and tiger prawn.

\section{Leading Commodity Sub Sector of Sea Fishery of West Sumatra Province}

In general, the share of West Sumatra fishery production to Indonesia in 2015 is around 3.60 percent. from the species of small pelagic fish, three biggest shares to national is torpedo, talangtalang, and bigeye respectively 31,55 percent, 12,01 percent and 1,107 percent. However, from the RCA value, the species of small pelagic fish which is including the leading commodity of West Sumatra in sequence are torpedo, talang-talang, bigeye, anchovy, bentong, green selar, yellow selar and mackerel because the RCA value greater than 1 .

Table 1 Production (ton) and Share (percent) of Small Pelagic Fish in Indonesia and West Sumatra

\begin{tabular}{lrrrccc}
\hline \multicolumn{1}{c}{ Type of Fish } & National & Share & $\begin{array}{c}\text { West } \\
\text { Sumatra }\end{array}$ & Share & $\begin{array}{c}\text { Share West Sumatra } \\
\text { to National }\end{array}$ & RCA \\
\hline Small Pelagic & 2015002 & 100.00 & 72652 & 100.00 & 3.61 & \\
$\begin{array}{l}\text { Fish } \\
\text { Torpedo }\end{array}$ & 48150 & 2.39 & 15193 & 20.91 & 31.55 & 8.75 \\
Talang-talang & 16201 & 0.80 & 1946 & 2.68 & 12.01 & 3.33 \\
Bigeye & 15037 & 0.75 & 1665 & 2.29 & 11.07 & 3.07 \\
Anchovy & 206636 & 10.25 & 19560 & 26.92 & 9.47 & 2.63 \\
Bentong & 16536 & 0.82 & 1181 & 1.63 & 7.14 & 1.98 \\
Greenstripe scad & 33288 & 1.65 & 2035 & 2.80 & 6.11 & 1.70 \\
Greenstripe scad & 93176 & 4.62 & 5442 & 7.49 & 5.84 & 1.62 \\
Mackerel & 325774 & 16.17 & 15483 & 21.31 & 4.75 & 1.32 \\
& & & & & & \\
\hline
\end{tabular}

From species of big pelagic fish, three biggest shares to the National is selendang shark (BSH), frigate tuna (FRI), cowboy shark (OCS), and selendang shark has the most share, with a share of more than 50 percent of national fish production of shark. But, when we see from the value of RCA>1, then the species of big pelagic fish that has the comparative advantage in sequence is selendang shark (BSH), kkut krai (FRI), cowboy shark (OCS), tenggiri board (GUT), bottle shark (PSK), black shrimp (BLM), fish screen (SFA) and shark mouse/monkey shark(THR). 
Table 2 Production (ton) and share (percent) of big pelagic fish in Indonesia and West Sumatra

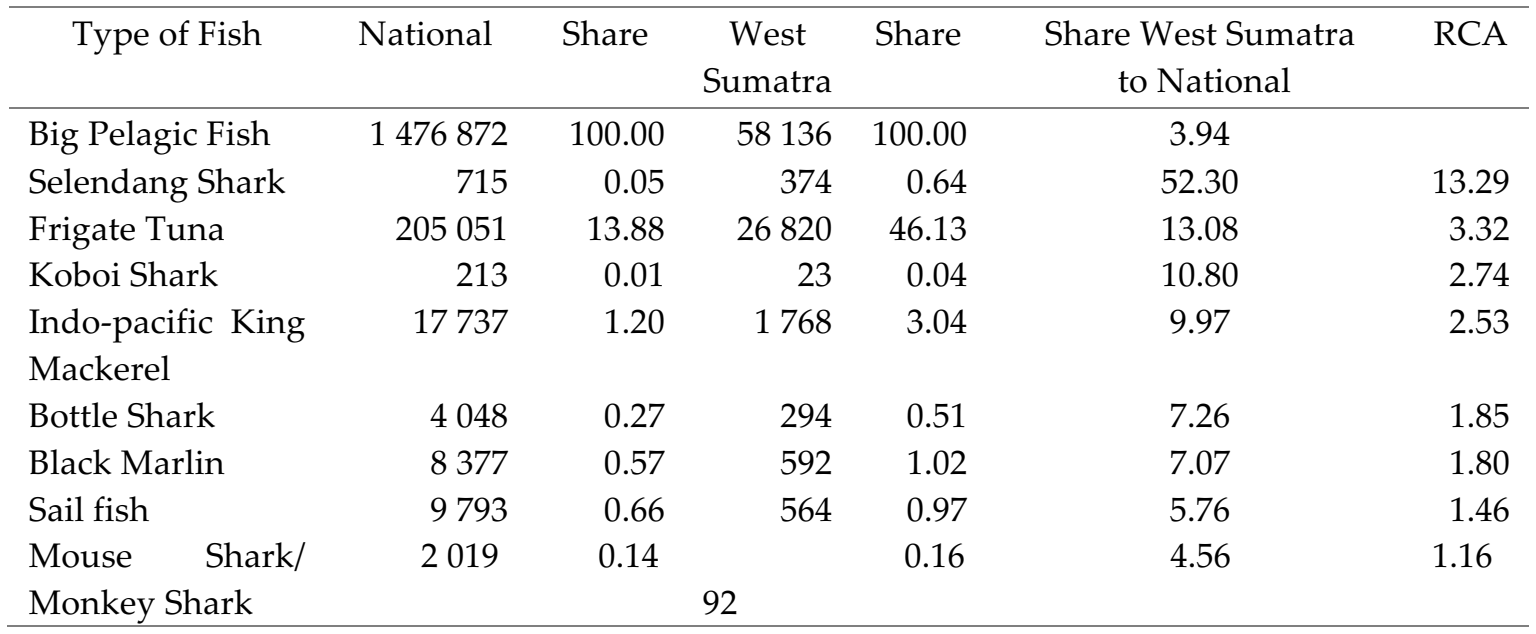

In the species of damersal fish, namely senuk, peperek and layur are the fishes that contribute the three largest to the national fishery production. Viewed from the value of RCA, fish senuk, peperek, large head hairtail, nomei / lomei, kapas-kapas, jenaha, gaji fish and giant trevally are damersal fish species that have comparative advantages in West Sumatra Province.

Table 3 Production (ton) and Share (percent) of damersal Fish in Indonesia and West Sumatra

\begin{tabular}{lrrrccr}
\hline \multicolumn{1}{c}{ Type of Fish } & National & Share & $\begin{array}{c}\text { West } \\
\text { Sumatra }\end{array}$ & Share & $\begin{array}{c}\text { Share West Sumatra to } \\
\text { National }\end{array}$ & RCA \\
\hline Damersal Fish & 1534404 & 100.00 & 56380 & 100.00 & 3.67 & \\
Senuk & 953 & 0.06 & 422 & 0.75 & 44.28 & 12.05 \\
Peperek & 86238 & 5.62 & 20537 & 36.43 & 23.81 & 6.48 \\
Layur & 69188 & 4.51 & 12531 & 22.23 & 18.11 & 4.93 \\
Biji nangka & 37902 & 2.47 & 3765 & 6.68 & 9.93 & 2.70 \\
Ikan & 3813 & 0.25 & 332 & 0.59 & 8.71 & 2.37 \\
nomei/Lomei & & & & & & \\
Kapas-kapas & 24176 & 1.58 & 1745 & 3.10 & 7.22 & 1.96 \\
Jenaha & 5622 & 0.37 & 367 & 0.65 & 6.53 & 1.78 \\
Ikan gaji & 3163 & 0.21 & 154 & 0.27 & 4.87 & 1.33 \\
Giant Trevally & 116152 & 7.57 & 5006 & 8.88 & 4.31 & 1.17 \\
\hline
\end{tabular}

Furthermore, from the species of reef fish, kerapu balong, kerapu karang and yellow tail are the fish with the highest production share to the national production. However, the types of fish that have a comparative advantage are kerapu balong, kerapu karang, yellow tail and napoleon fish.

Table 4 Production (ton) and share (percent) of coral fish in Indonesia and West Sumatra

\begin{tabular}{|c|c|c|c|c|c|c|}
\hline Type of Fish & National & Share & $\begin{array}{c}\text { West } \\
\text { Sumatra }\end{array}$ & Share & $\begin{array}{l}\text { Share west } \\
\text { Sumatra } \\
\text { to National }\end{array}$ & RCA \\
\hline Coral Fish & 289892 & 100.00 & 4389 & 100.00 & 1.51 & \\
\hline Kerapu balong & 9943 & 3.43 & 435 & 9.91 & 4.37 & 2.89 \\
\hline Kerapu Karang & 68251 & 23.54 & 1746 & 39.78 & 2.56 & 1.69 \\
\hline Yellow Tail Fish & 79484 & 27.42 & 1457 & 33.20 & 1.83 & 1.21 \\
\hline Napoleon Fish & 1322 & 0.46 & 24 & 0.55 & 1.82 & 1.20 \\
\hline
\end{tabular}


Thus, we can conclude that fish species with RCA value 1 indicate that West Sumatra Province has a comparative advantage in producing I higher than other provinces in Indonesia. Therefore, capture fisheries for these fish species need to be developed and have the potential to develop in the future.

These leading commodities, can be used as one of the priority of fish commodity development in West Sumatra Province. With priority development on the leading fish commodity is expected to increase the number of fish obtained, which in turn can increase the income of fishermen and contribution to the economy of West Sumatra Province.

\section{Conclusions}

The results of the study found that the leading commodities of marine fishery in West Sumatra Province are as follows. First, species of small pelagic fish are torpedo, daun bambu/talang-talang, bigeye, anchovy, bentong, greenstripe scad, yellowstripe scad and mackerel. Second, species of big pelagic fish are selendang shark (BSH), frigate tuna (FRI), koboi shark (OCS), indo-pacific king mackerel (GUT), bottle shark (PSK), black marlin (BLM), sail fish (SFA) and mouse shark/ monkey shark (THR). Third, species of damersal fish are senuk, peperek, layur, biji nangka, nomei/lomei, kapas-kapas, jenaha, gaji fish and giant trevally. Finally, species of coral fish are kerapu balong, kerapu karang, yellow tail fish and napoleon fish.

\section{References}

Arti, B. D. (2011). Analisis Strategi Kebijakan Pemerintah Terkait dengan Perkembangan Industri Kelapa Sawit Nasional (Studi Kasus di PTPN IV Medan Sumatra Utara). Master Thesis. IPB.

Bank of Indonesia. (2007). Potensi Ekonomi Daerah dalam rangka Pengembangan Komoditi Unggulan Usaha Mikro, Kecil dan Menengah (UMKM) di Propinsi Maluku Utara. Laporan Hasil Penelitian.

Bank Indonesia bekerjasama dengan Fakultas Ekonomi UNP. (2011). Komoditi/Produk/Jenis Usaha Unggulan UMKM di Sumatra Barat. Bank Indonesia: Padang.

BPS Sumbar (2012). Sumbar Dalam Angka 2012. Padang: BPS.

Barro, R. J. (1991). Economic growth in a cross section of countries. The Quarterly Journal of Economics, 106(2), 407-443.

Barro, R. J. (2001). Human capital and growth. The American Economic Review, 91(2). Papers and Proceedings of the Hundred Thirteenth Annual Meeting of the American Economic Association (May, 2001), 12-17.

Dumgair, D. (2011). Strategi pengembangan ekonomi lokal berbasis perikanan di kabupaten kepulauan Aru. Master Thesis. IPB: Bogor.

Eng, P.v.d. (2008). The sources of long-term economic growth in Indonesia, 1880-2007. Working Papers in Economics \& Econometrics. Australian National University. ISBN: 0868314994.

Mankiw, N.G., David, R., \& David N. W. (1992). A contribution to the empirics of economic growth. The Quarterly Journal of Economics, 107(2), 407-437.

Romer, Paul M. (1994). The origins of endogenous growth. The Journal of Economic Perspectives, 8(1), 322.

Saaty. (2008). Decision making with the analitikal hirarki process. Intj. Service Scincist, 1(1).

Sudirman. (2007). Peranan IPTEK dalam pembangunan sumber daya kelautan Secara berkelanjutan. Makalah disampaikan pada Kongres Ilmu Pengetahuan Wilayah untuk Kawasan Timur Indonesia, di Gedung PKP University of Hasanuddin. Makassar, 23 - 24 April 2007. 